\title{
A CONTRIBUTION TO OUR KNOWLEDGE OF THE TAPEWORMS OF POULTRY.
}

\author{
By F. J. MEgGiTT, M.Sc., Рн.D., \\ Assistant Helminthologist, University of Birmingham. \\ (From the Research Laboratory in Agricultural Zoology, \\ University of Birmingham.)
}

(With Plate XVI and Plate XVII, Figs. 8-11, and 1 Text-figure.)

\begin{tabular}{|c|c|c|c|c|c|}
\hline \multicolumn{6}{|c|}{ INDEX. } \\
\hline Cotugnia digonophora (Pasq.) & . & • & . & . & 301 \\
\hline Cotugnia brotogerys Meggitt & . & . & . & . & 304 \\
\hline Cotugnia fastigata n. sp. & . & . & . & . & 304 \\
\hline Hymenolepis columbae (Zed $)$ & . & • & . & $\cdot$ & 306 \\
\hline Hymenolepis coronula (Duj.) & . & • & $\cdot$ & • & 307 \\
\hline Hymenolepis gracilis (Zed.) & 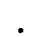 & 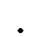 & . & . & 308 \\
\hline
\end{tabular}

THE following paper is an account of the results obtained by the study of Cestodes sent to this Department for identification. For the most part, the tapeworms were species with a wide distribution and with many previous records of their occurrence. Among them were several whose anatomy, wellknown in many respects, had been inadequately described with regard to characters useful, if not essential, for identification.

The present paper, with the exception of that portion concerning the new species Cotugnia fastigata, is an attempt to deal with such characters and so complete already existing descriptions.

I wish here to express my indebtedness to Prof. Nuttall, F.R.S., for specimens of Hymenolepis columbae (Zed.), H. coronula (Duj.), H. gracilis (Zed.), and Cotugnia fastigata n. sp., collected by Dr H. H. Marshall at Rangoon, and to Dr C. L. Boulenger for those of Cotugnia digonophora (Pasq.), from Mesopotamia.

COTUGia digonophora (Pasquale, 1890).

The genus Cotugnia was created by Diamare (1893) for those avian Cestodes which have a double set of male and female reproductive organs in each proglottis, and a rostellum armed with $\mathrm{T}$-shaped hooks. The type species is C. digonophora (Pasq.), a form described under the name of Taenia digonophora by Pasquale in 1890 from chickens in Abyssinia. Since that date, 
with the exception of a paper by Khitrow (1900) inaccessible to me, the species has not been recorded. Pasquale's description is incomplete in many respects so that, although through the work of Fuhrmann (1909) on the species C. crassa Fuhr., C. collini Fuhr. and C. polycantha Fuhr., the genus is well defined, the type species has remained practically undescribed. Three complete tapeworms from chickens in Mesopotamia were handed to me for identification. These I believe to be specimens of $C$. digonophora (Pasq.), and take the opportunity to compile as full an account as possible of the anatomy of this type species.

The sizes of the strobilae are $107 \mathrm{~mm} . \times 4 \mathrm{~mm} ., 80 \mathrm{~mm} . \times 4 \mathrm{~mm}$., $26 \mathrm{~mm} . \times 2.5 \mathrm{~mm}$. and $22 \mathrm{~mm} . \times 2.5 \mathrm{~mm}$. The scolex (Pl. XVII, fig. 9) is $0.66 \mathrm{~mm}$. long $\times 1.07 \mathrm{~mm}$. broad, with four unarmed suckers $0.36 \mathrm{~mm}$. long $\times$ $0.25 \mathrm{~mm}$. wide, arranged two dorsally and two ventrally. The rostellum is $0.16 \mathrm{~mm}$. in diameter, armed with a double crown of hooks $0.0122 \mathrm{~mm}$. long, of the usual Davainea shape, the hooks on each row being of the same size and alternating with each other, with but little difference in their anterior level. The rostellum itself is a simple muscular structure sunk between four large lobes which completely hide it. All proglottides are broader than long.

These measurements do not agree with those quoted by Stiles $(1896$, p. 30) "Strobila $40 \mathrm{~mm}$. to $80 \mathrm{~mm}$. by $8 \mathrm{~mm}$. broad and in contracted condition about $1 \mathrm{~mm}$. thick; head $1.4 \mathrm{~mm}$. by $1.12 \mathrm{~mm}$., rostellum with a crowded crown (in a single row) of very small hooks $8.35 \mu$ long; base of rostellum $0.22 \mathrm{~mm}$. by $0.15 \mathrm{~mm}$., suckers globular, prominent, $0.35 \mathrm{~mm}$. in diameter. Neck short. Anterior segments broader than long, posterior segments longer than broad. Genital pores double in about the middle of the lateral margins; two ovaries in each segment; eggs evidently arranged in egg sacs."

These differences in the measurements and the shape of the proglottides, characters indefinite and liable to variation, are probably the result of individual variation in the tapeworms examined and can therefore be safely neglected.

The longitudinal musculature (Pl. XVII, fig. 11) is in two layers. The innermost (l.m.) consists of numerous bundles of loosely packed fibres, approximately 20 fibres to a bundle. Internally it is bounded by a single (t.m.) and externally by a double $\left(t^{\prime} . m^{\prime}\right.$.) layer of transverse muscles, the two layers of the latter separated by a narrow stratum of parenchyma. Numerous dorsoventral fibres cross these two last layers and pass between the inner longitudinal muscle bundles. Externally to the transverse muscles mentioned is a widely diffused layer of longitudinal muscles $\left(l^{\prime} . m^{\prime}.\right)$. Internally these form very compact bundles of very few fibres, approximately 10 per bundle, but diminish gradually to isolated fibres which do not extend as far as the cuticle. Both these two longitudinal muscle layers extend posteriorly into segments containing mature eggs, but only the inner extends anteriorly into the scolex. There it is much stronger, the bundles being more numerous and more compact, and forming an almost continuous layer which ceases at the posterior half of the suckers. 
The excretory system consists of the usual four longitudinal vessels, two dorsal and two ventral. The former are exceedingly minute and are external to the two latter. At the posterior limit of each proglottis, the two ventral vessels communicate by a large transverse commissure. No such commissure could be found between the two dorsal, probably on account of their small size. In segments filled with mature eggs, both dorsal and ventral vessels disappear. In the anterior segments they are of equal size. In the scolex they run between the suckers in a wavy course, giving off numerous anastomosing branches and opening into a circular commissure, immediately posterior to the rostellum.

There are two complete sets of genital organs in each proglottis (Pl. XVII, fig. 10). The genital pore is half way along each lateral margin or else slightly anterior. A very shallow genital cloaca is present. The genital canals run dorsal to both excretory vessels and to the nerve.

The cirrus-pouch is long and slender and devoid of special retractor muscles. It only extends as far as the nerve, not past it as Fuhrmann (1909, p. 120) states, "Der Cirrusbeutel ist langgestreckt $(0.3 \mathrm{~mm}$.) und geht über den Längsnerv bis zu dem nach aussen vom ventralen Exkretionsstamm gelegenendorsalen Exkretionsgefäss," and is straight. The cirrus is armed with fine spines and has a small terminal enlargement. It runs in a straight line half-way along the cirrus-pouch and then merges into the vas deferens; after this point the cirrus-pouch is less muscular. The vas deferens is twice the diameter of the cirrus and is uncoiled while still within the pouch. On emerging, it coils into a loose ball and then, running posteriorly, breaks up into the vasa efferentia. There is no vesicula seminalis, the coils of the vas deferens functioning instead. The testes $(t$.$) form a broad band across the proglottis,$ are approximately 100 in number and are posterior to the female glands. None are to be found in the anterior half of the segment. They surround dorsally and laterally, but not ventrally, the longitudinal excretory canal and extend as far as the longitudinal nerve. Dorso-ventrally they form an indistinct double layer in the centre of the proglottis, being three deep at the extremities and only one deep in the centre.

The vagina $(v$.) opens posteriorly to the cirrus and runs slightly posteriorly to open into a spindle-shaped receptaculum seminis (r.s.) situated just internally to the excretory vessels. The ducts from the receptaculum seminis take their usual course. The ovary (ov.) is crescent shaped with the con- cavity directed posteriorly and internally, and with the convex side deeply lobed. The yolk-gland $(y . g$.$) is a shapeless irregularly lobed gland lying$ posteriorly and internally to the ovary. Both ovary and yolk-gland lie immediately internally to the longitudinal excretory vessels with the ovary half-way between the posterior and anterior borders of the segment. The shell-gland is very compact, non-lobed, and lies on the dorsal surface between the ovary and yolk-gland. A definite uterus is not developed. The oviduct, after passing through the shell-gland, persists for an exceedingly short distance 
as a rather wide indistinct parenchymatous tube filled with eggs and ends blindly in the parenchyma. In a proglottis at this stage of development the anterior half is already full of fertilised eggs; in the stage immediately preceding, the uterine tube has more definite walls but still ends blindly, while but few eggs are visible in the proglottis. In proglottides ready for detachment, the eggs fill the entire segment, extending laterally to the excretory vessels almost to the margin of the segment. Adjacent proglottides are separated only by a thin plate of parenchyma. The egg is ellipsoidal, measuring $0.63 \mathrm{~mm}$. $\times 0.583 \mathrm{~mm}$. and the onchosphere $0.288 \mathrm{~mm} . \times 0.249 \mathrm{~mm}$.

\section{COTUGNIA BROTOGERYS (MegGITT, 1915).}

This species from a parakeet, Brotogerys tirica, has already been described in detail (Meggitt, 1915). Revision of the material has recently shown that this description is inaccurate in one respect. It has been stated (p. 54) that the parenchymatous capsules each contain several ova. This is not correct. In young segments the eggs lie singly in separate capsules. As the proglottis matures the number of eggs increases and the capsules become packed so closely together that in many cases the walls separating them disappear. The capsules thus appear each to contain several ova.

The testes surround the longitudinal excretory vessel except on the dorsal surface, a condition exactly opposite to that in $C$. digonophora. Anteroposteriorly, the band of testes consists of five rows; dorso-ventrally they lie in the centre of the proglottis.

\section{COTUGNIA FASTIGATA N. SP.}

Amongst a large number of $H$. coronula (Duj.) from domestic ducks, Rangoon, were found several complete specimens of a Cotugnia. Upon examination these proved to represent a new species for which $I$ propose the name Cotugnia fastigata n. sp. and which may be identified by the key attached to the following description.

The length is $30 \mathrm{~mm}$., the breadth $6 \mathrm{~mm}$., and all the proglottides are broader than long. In shape the strobila (Pl. XVI, fig. 4) is triangular, widest at the base and narrowing gradually towards the head. The scolex is $0.5-0.6 \mathrm{~mm}$. diameter, and is provided with four unarmed suckers and an armed rostellum. The latter is $0.29 \mathrm{~mm}$. diameter, and bears approximately 200 hooks, $0.02 \mathrm{~mm}$. long, arranged in a double row, the hooks of the two rows alternating. It proved impossible to ascertain the exact shape of the hooks owing to the difficulty of isolating them; one figured in Text-fig. 1 is from a section and has obviously been cut at the place marked $x$. The base of each hook (PI. XVII, fig. 8) has a fine sheath of muscle (m.) surrounding it. Posteriorly this merges into a fine muscle strand $0.5 \mu$ diameter which, uniting with adjacent muscle strands, ultimately joins the body longitudinal muscles. Externally to the hooks and surrounding the rostellum is a thin sheath of transverse muscles. 
The scolex (Pl. XVI, fig. 7) is attached to several villi which, free at first, in course of time become fused together into a solid mass at their distal ends but with the proximal ends still showing traces of their original formation. To this thickened lump the scolex fixes itself by the rostellor hooks. The centre of the rostellum, instead of being applied closely to the mass of villi, retracts, so as to leave between the scolex and the intestine a conical cavity, often partially filled with mucous, round the circumference of whose base the rostellum is still firmly fixed by its hooks. The suckers appear to play a temporary part in the fixation of the worm to the intestine; immediately on death they relax their hold while the rostellum generally remains firmly imbedded. The scolex may hang freely in the lumen of the intestine or may be sunk among the villi, but it never penetrates the submucosa.

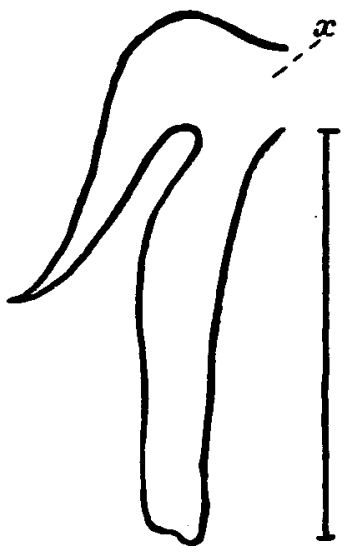

Text-fig. 1. Cotugnia fastigata n. sp., Hook from Rostellum.

The musculature (Pl. XVI, fig. 6) consists of three layers of longitudinal muscles each bounded internally by a thin layer of transverse ones. The innermost longitudinal musculature (l.m.) consists of a number of fibres aggregated together into large irregular bundles; the bundles of the middle layer $\left(l^{\prime} . m^{\prime}.\right)$ are smaller, more compact, composed of fewer fibres, and arranged more regularly, while externally to them isolated fibres $\left(l^{\prime \prime} . m^{\prime \prime}\right.$.) extend up to the cuticula.

The dorsal longitudinal excretory vessels are absent from proglottides containing genital organs; the ventral persist to the posterior end of the strobilus, and communicate by the usual transverse commissure at the posterior border of each proglottis.

The genital pore (Pl. XVI, fig. 5) is situated at the limit of the anterior quarter of the proglottis margin, and into it open anteriorly and posteriorly the cirrus-sac and vagina respectively.

The testes $(t$.) extend as a narrow band along the posterior border of the proglottis. Antero-posteriorly, this band has a uniform width, consisting of two to three rows of testes; dorso-ventrally, it is thickest laterally where 
there are three layers of testes extending from the dorsal to the ventral surface and thinnest in the centre where there is only a single layer on the dorsal surface. Laterally the testes surround the ventral excretory canal and extend. as far as the nerve. There is also a small group of testes situated between the ovary and the excretory canal. The anterior portion of the proglottis is entirely free from them. The cirrus-sac (c.s.) is small and narrow but long in proportion to its width, and extends as far as the lateral nerve. Between it and the testes, the vas deferens forms a closely packed bundle of coils surrounded by numerous gland cells. Inside the sac, the vas deferens coils once or twice and then opens into the short straight cirrus.

The vagina runs in a straight course laterally to open into a small spindle-shaped receptaculum seminis (r.s.). The ovary (ov.) is deeply divided into several blunt lobes closely packed together. It lies posterior and ventral to the receptaculum seminis and close to the excretory canal. Posterior and slightly aporal to it is the compact yolk-gland (y.g.) surrounded laterally by the testes.

The uterus $(u$.) is present as a narrow branched tube anterior to the ovary, but soon disappears, the mature eggs lying singly in capsules in the parenchyma.

\section{Key to Species of Cotugnia.}

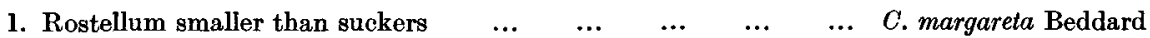

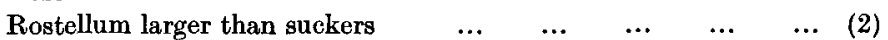

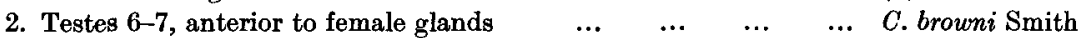
Testes numerous, lateral or posterior to female glands $\quad \ldots \quad \ldots$ (3)

3. Testes clearly divided into two lateral groups $\quad \ldots \quad \ldots \quad \ldots$ (4)

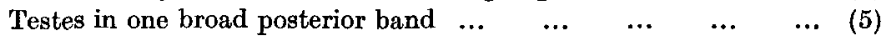

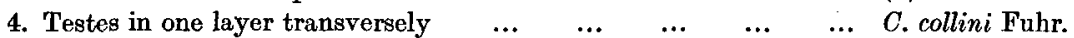

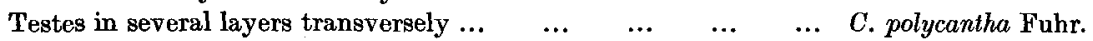

5. Cirrus-sac extending beyond ventral longitudinal excretory vessel C. fuhrmanni Bacz. Cirrus-sac not reaching ventral longitudinal excretory vessel $\ldots$ (6)

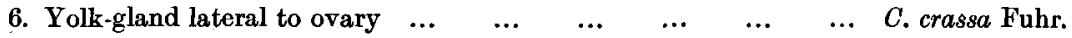

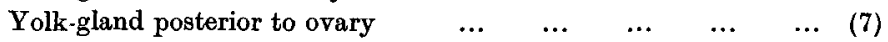

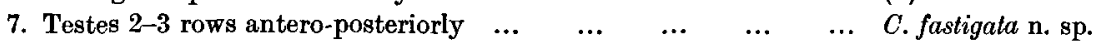
Testes 5 rows antero-posteriorly $\quad \ldots \quad$...

8. Testes dorsal and lateral to longitudinal excretory vessels $\quad \ldots \quad$ C. digonophora (Pasq.) Testes ventral and lateral to longitudinal excretory vessels $\quad \ldots \quad C$. brotogerys Meggitt

(C. inaequalis Fuhrmann 1909 has not been described sufficiently to allow of its inclusion in this table.)

\section{HYMENOLEPIS COLUMBAE (ZEDER, 1800).}

The specimens of this species had been collected from pigeons, Rangoon, and consisted of portions of strobila in various stages of development. No scoleces were found. According to Ransom (1909, p. 97) this species is identical with the $H$. sphenocephala (Rud.) described by Fuhrmann (1906, p. 449), whose description, with the exception of the points mentioned below, was fully corroborated by my preparations. 
The genital pore is much more anterior than is figured by him, lying in the anterior quarter of the proglottis; the genital cloaca is also much shallower, being only a small depression. The vagina consists of two separate parts. The first, muscular and with an extremely wide lumen, runs dorsally from the genital cloaca as far as the inner limit of the sacculus accessorius, there to open into a more muscular duct with no apparent lumen. This latter portion is spirally coiled, and runs ventrally and anteriorly to open into the receptaculum seminis. The difference between the two parts of the vagina is very marked. Of the two aporal testes, Fuhrmann (1906 a, p. 450) states "der vordere (liegt) aber etwas ausserhalb des hinteren antiporalen Hodens." Preparations and sections showed this clearly. Though the two testes often appeared to lie one directly anterior to the other, yet in every case a projecting tongue from the anterior one lay external to the posterior, and a distinction between internal and external could be made.

\section{HYMENOLEPIS CORONULA (DUJARDIN, 1845).}

This cestode of ducks has been described by many authors, in particular by Wolffhügel $(1900$, p. 165), but although most of its anatomy is well-known the following points have escaped attention. The specimens I received were taken from domestic ducks in Rangoon.

The three testes (Pl. XVI, fig. 1, t.) are arranged as Fuhrmann (1906a, p. 733) states, one poral and two aporal, the edges of the poral and the inner aporal testes touching in young segments but being gradually separated by the growth of the female glands between them. The arrangement of the two aporal testes varies according to the state of contraction of the segment; in proglottides extremely contracted, as in the one figured, the three testes are in the same straight line; in proglottides extended, one aporal testis lies anterior to and internal to the other. In all cases though, the outer testis has a small projection lying posteriorly to the inner, so that even when in the same straight line a distinction into anterior testes and posterior testis can be made. Wolffhügel (p. 171) states, "Die drei Hoden erreichen bei Dicranotaenia coronula in höchster Reife eine solche Grösse, dass sie bis an die dorsale und ventrale Längsmuskulatur stossen." This I have not found to be the case, the three testes lying well within the musculature. The cirrussac (c.s.) extends as far as, or just passes, the ventral longitudinal excretory vessel, and is two-thirds filled by the internal vesicula seminalis $\left(v^{\prime} . s^{\prime}.\right)$, rather a larger proportion than figured by Wolffhügel (Pl. VII, fig. 103). The cirrus extending from this vesicula seminalis to the genital pore is straight and the small sacculus accessorius present is a straight tube of uniform diameter with no terminal enlargement; both these observations do not agree with the figure above mentioned. The external vesicula seminalis (v.s.) is small, and spindle shaped, and lies dorsal and lateral to the receptaculum seminis.

The female glands (Pl. XVI, fig. 2) are posterior and ventral, and occupy one-third of the proglottis breadth. The bluntly lobed yolk-gland $(y . g$.$) lies$ 
on the posterior and ventral surface of the segment and is surrounded on all sides except the posterior by the narrow: unlobed ovary (ov.).

When fully developed, the receptaculum seminis (r.s.) extends from the ventral longitudinal excretory vessel to a little over half-way across the segment. It is slightly funnel-shaped, the inner end being rather larger than the outer. The uterus $(u$.$) in its early stages is a long narrow sac twisted upon$ itself so that its cavity appears to be divided by septa. Later it increases in size and occupies the whole of the proglottis, extending past the excretory vessel as far as the cuticula. At this stage the proglottis is a mere egg-sac, but with no communication with adjacent segments. As was the case with other observers, no mature eggs could be found.

\section{HYMENOLEPIS GRACILIS (ZEDER, 1803).}

The specimens of this species were obtained from the.intestine of domestic ducks, Rangoon, and sections confirm Wolffhügel's account. The following additional points were noticed. The genital pore (Pl. XVI, fig. 3, g.p.) is extremely anterior, in the anterior quarter of the proglottis margin, and is often covered by the overlapping of the preceding segment. The cirrus-sac (c.s.) does not, as Lühe (1910, p. 61) states, barely reach the centre line of the proglottis, but extends well past it, nearly to the aporal longitudinal excretory vessel. The testes $(t$.$) are arranged as Fuhrmann (1906 b,$ p. 733) states, one poral and two, aporal; of the latter the one is always external and anterior to the other. As stated by other investigators no transverse commissures could be traced between the longitudinal excretory vessels of opposite sides. A large number of minute branches are given off during their course, particularly in the neighbourhood of the posterior margin of the proglottis and as these latter branches penetrate some distance into the segment and could often be traced half-way across it, it is a reasonable supposition that through them the opposite excretory vessels communicate.

\section{REFERENCES.}

Diamare, V. (1893). Note su' Cestodi. Boll. Soc. Nat. Napoli. Ser. 1. vir. 9.

DUJARdin, F. (1845). Histoire naturelle des Helminthes, ou vers intestinaux. Paris.

Euhrmann, O. (1906, a). Die Hymenolepis Arten der Vögel. Centrbl. Bakt. Abt. 1, Orig., XII. $440-452$.

$(1906, b)$. Die Hymenolepis Arten der Vögel. Ibid. xLII. 620-628. (1909). Neue Davaineiden. Ibid. xurx. 116-122.

Govar, L. H. (1911). A monograph of the tapeworms of the subfamily Avitellininae, being a revision of the genus Stilesia, and an account of the histology of Avitellina centripunctata (Riv.). Quart. Journ. Micr. Sci., n. s. LV. 317.

Kнттrow, M. S. (1900). Sur la présence de la Cotugnia digonophora à Kharkov et de son parasite ver rond. Trudui Kharkov Univ., xxxv. 27.

KRABBE, H. (1869). Bidrag til Kundskab om Fuglenes Baendelorme. Kgl. Dansk. Vidensk. Selsk. Skrift., R. 5. Naturvid. og math. Afd. 8, vr.

Linstow, O. v. (1905). Helminthen der Russischen Polar-Expedition 1900-1903. Mém. Acad. Imp. Sci., Petrograd, Ser. vIIr. Cl. Phys.-Math., xvirr. 
Lüнt, M. (1910). Parasitische Plattwürmer. II. Cestodes in: Die Süsswasserfauna Deutsch. lands, hgb. Prof. Brauer, Jena, H. 18.

MrgatT, F. J. (1915). A new species of tapeworm from a parakeet, Brotogerys tirica. Parasitology, virr. 42.

Pasquale, A. (1890). Le tenie dei polli di Massana (descrizione di una nuova specie). Giorn. Internaz. Sci. Med., xII. 905.

RaItuIEt, A. (1893). Traité de zoologie médicale et agricole. 2me éd., Paris.

Ransom, B. H. (1909). The taenioid cestodes of North American birds. Proc. Smith. Inst., U.S. Nat. Mus., Bull. 69.

Stries, C. W. and Hassali, A. (1896). Tapeworms of Poultry. U.S. Dept. of Agric., Bur. Anim. Indus., Bull. 12.

WoLFTHÜGEL, K. (1899). Beitrag zur Kenntnis der Vögelhelminthen. Inaug. Diss., Basel.

For description of Plates XVI and XVII see p. 313. 